\title{
INTEGRATED ASSISTANCE MODEL IN THE FRAMEWORK OF STRENGTHENING THE FOUNDATION OF MSMES
}

\author{
Lokita Rizky Megawati *)1 \\ *) School of Business, IPB University \\ Jl. Pajajaran, Bogor 16151
}

\begin{abstract}
The MSMEs assistance program is a model of MSMEs development that focuses on efforts to improve the institutional system (capacity building) and managerial aspects of MSMEs, which are carried out intensively and continuously, by actively involving professional MSMEs consultants. This consultant is tasked with providing consultation and coaching, specifically relating to the daily operations of MSMEs. The purpose of this paper are to 1) explain what problems are being faced as obstacles to the development of MSMEs; 2) understand the assistance requirements for MSMEs; 3 ) design an integrated assistance model as a solution for the development of MSMEs in Cibaduyut. This research uses a qualitative methodology. The data used consisted of primary data and secondary data. Primary data were obtained from direct field observations, in-depth interviews with UPT IKM Cibaduyut and several shoe craftsmen in Cibaduyut. Secondary data was obtained from previous research reports, journals, internet sites, and sourcebooks. The results prove that implementing the integrated assistance model are expected to improve the ability of MSMEs to analyze the results of business simulations, compile financial models so as to be able to utilize capital well, and make conclusions on the performance of companies or organizations with a high degree of accuracy and clarity. This study concludes that a asisstance program is needed to develop an independent and optimally developing MSMEs. The steps in the assistance program include planning, implementation, evaluation and development.
\end{abstract}

Keywords: assistance program, Cibaduyut, integrated assistance model, MSMEs

\begin{abstract}
Abstrak: Program pendampingan UMKM adalah model pengembangan UMKM yang berfokus pada upaya peningkatan sistem kelembagaan (peningkatan kapasitas) dan aspek manajerial UMKM, yang dilakukan secara intensif dan berkesinambungan, dengan secara aktif melibatkan konsultan UMKM profesional. Konsultan ini bertugas memberikan konsultasi dan pembinaan, khususnya yang berkaitan dengan kegiatan operasional harian UMKM. Tujuan dari makalah ini adalah untuk 1) menjelaskan masalah apa yang dihadapi sebagai hambatan untuk pengembangan UMKM; 2) memahami kebutuhan pendampingan untuk UMKM; 3) merancang model pendampingan terintegrasi sebagai solusi untuk pengembangan UMKM di Cibaduyut. Penelitian ini menggunakan metodologi kualitatif. Data yang digunakan terdiri dari data primer dan data sekunder. Data primer diperoleh dari observasi lapangan langsung, wawancara mendalam dengan UPT IKM Cibaduyut dan beberapa pengrajin sepatu di Cibaduyut. Data sekunder diperoleh dari laporan penelitian sebelumnya, jurnal, situs internet, dan buku sumber. Hasil tersebut membuktikan bahwa menerapkan model pendampingan terintegrasi diharapkan dapat meningkatkan kemampuan UMKM untuk menganalisis hasil simulasi bisnis, menyusun model keuangan sehingga dapat memanfaatkan modal dengan baik, dan membuat kesimpulan pada kinerja perusahaan atau organisasi dengan tingkat akurasi dan kejelasan yang tinggi. Studi ini menyimpulkan bahwa program pendampingan diperlukan untuk mengembangkan UMKM yang mandiri dan berkembang secara optimal. Langkah-langkah dalam program pendampingan meliputi perencanaan, implementasi, evaluasi dan pengembangan.
\end{abstract}

Kata kunci: program pendampingan, Cibaduyut, model pendampingan terintegrasi, $U M K M$

\footnotetext{
${ }^{1}$ Corresponding author:

Email: lokita.rizky@apps.ipb.ac.id
} 


\section{INTRODUCTION}

Micro, Small and Medium Enterprises play a role in advancing the Indonesian economy. In addition to being an alternative for new jobs, MSMEs also played a role in driving the pace of economic growth after the 1998 monetary crisis when large companies had difficulty developing their businesses (Susila, 2017). At present, MSMEs have contributed greatly to regional and state revenues in Indonesia. Based on data from the Ministry of Cooperatives and SMEs from BPS in 2016 showed the contribution of MSMEs which contributed 60.34 percent of the total national GDP. This provides evidence that small businesses play an important role in overall business activities, especially in the face of future economic growth in a country.

MSMEs are a form of community small business whose founding is based on one's initiative. Most people think that MSMEs only benefits certain parties. When in fact MSMEs are very instrumental in reducing the unemployment rate in Indonesia. MSMEs can absorb many Indonesian workers who are still unemployed (Chabib, 2016).

Development of Micro, Small and Medium Enterprises (MSMEs) is one of the efforts made in overcoming the problem of unemployment, poverty, or the problem of widening the gap between sectors or businesses. MSMEs has strategic potential in improving the national economy. In addition to providing goods and services, MSMEs can absorb a large workforce. These MSMEs are also a group that is proven resilient to the shocks of the economic crisis that hit (Hafsah, 2004).

MSMEs also utilize various potential natural resources in areas that have not been treated commercially (Budi, 2011). MSMEs can help process this Natural Resource. This contributes greatly to regional income and national income. MSMEs have limitations in a variety of ways, including limited access to market information, limited market reach, limited networks, and limited access to strategic business locations (Tambunan, 2012). Some of the common problems faced by MSMEs, especially those classified as MSMEs, are the limited quality of resources, market access and capital. Capital is not the only obstacle faced by MSMEs, as many people have predicted. There are many non-capital constraints, which actually become a crucial problem, such as assistance from the government, banking, and academics towards MSMEs (Iyuk Wahyudi, 2009). Without managerial enhancement and market assistance, it will only add to a series of stories of failures in various MSMEs empowerment programs. Various efforts have been made by the government which include conducting coaching through the Technical Office, forming an MSMEs advisory team, instituting Bank Partner Financial Consultants, requesting bank commitments in MSMEs financing in its Business Plan and also providing revolving funds sourced from the Regional Revenue and Expenditure Budget or profit-sharing State/Regional-Owned Enterprises are ruled out (Marliyah, 2016).

Cibaduyut is an example of an MSMEs which is a center for the production and sale of shoes in West Java that has potential and deserves to be developed because it is a regional asset. The products produced at Cibaduyut are actually able to compete in international market. The products offered also have varied models and are of high quality. With all the advantages that have been explained, Cibaduyut industrial area should be more developed. However, the current condition with the presence of ASEAN-China Free Trade Area (ACFTA) has weakened the Cibaduyut shoe entrepreneurs. The stretching of the economy in the Cibaduyut center is quite because of the large number of imported products. As a result, the turnover of craftsmen fell by 40 percent. This resulted in 254 craftsmen and more than 2,000 jobs being threatened (Solehudin, 2019).

Table 1 shows there was a decrease in numbers from 2012 to 2014, both in the business unit, labor, and annual production at the shoe center in Cibaduyut, until finally there was a very significant decline in 2016. The data showed that Cibaduyut's business unit had only 95 units left due to the low reliability of producers reaching the specified time target to complete consumer orders so that sales targets were not met so that it affected the purchasing power of consumers who were reluctant to order products.

Table 1. Potential cumulative data at cibaduyut shoe centers

\begin{tabular}{cccc}
\hline \multirow{2}{*}{ Year } & \multicolumn{3}{c}{ Potency } \\
\cline { 2 - 4 } & $\begin{array}{c}\text { Business } \\
\text { unit }\end{array}$ & $\begin{array}{c}\text { Labor } \\
\text { (people) }\end{array}$ & $\begin{array}{c}\text { Production per year } \\
\text { (pairs) }\end{array}$ \\
\hline 2012 & & & 4.092 .300 \\
2014 & & 3.008 & 3.114 .022 \\
2016 & 95 & - & - \\
\hline
\end{tabular}

Source: Bandung City Department of Trade and Industry, 2018 
In line with this, based on the results of interviews conducted that there is a sluggish business in the Cibaduyut area. The sluggishness is caused by poor product marketing, improper capital management, and less than optimal management systems. Constraints that occur due to lack of knowledge of entrepreneurs in terms of managerial, marketing, and capital management. To overcome these obstacles, assistance is needed for MSMEs. The MSMEs assistance program is an MSMEs development model that focuses on efforts to improve the safety system (MSMEs), and the managerial aspects of MSMEs, carried out intensively and managed, using active consultants of MSMEs professional consultants (Iyuk, 2009). These consultants provide advice (advisor) and consultancy, specifically relating to the daily operations of MSMEs. Assistance is basically an aid for the community in developing various potentials needed to achieve a better quality of life (Sumardjo, 2014). Based on the background above we want to review how to empower MSMEs in the Cibaduyut with the title "Integrated Assistance Model in the Framework of Strengthening the Foundation of MSMEs."

The purpose of this research are to 1) explain what problems are faced as obstacles to the development of MSMEs; 2) understanding the terms of assistance for MSMEs; 3) design an integrated assistance model as a solution to the development of MSMEs in Cibaduyut.

\section{METHODS}

The study used a qualitative methodology. Qualitative methodology is research methods used to examine natural object conditions where the researcher is a key instrument. Data collection techniques are carried out by through observation, interviews, and literature review. Data analysis is inductive and qualitative research results emphasize the meaning rather than generalization. Qualitative research also builds multiperspective interpretations from a variety of input sources and informants involved in research, not just from researchers (Soegiyono 2014).

The data used consisted of primary data and secondary data. Primary data were obtained from going to the field directly, in-depth interviews with UPT IKM Cibaduyut and several shoe craftsmen in Cibaduyut. Secondary data was obtained from several pieces of literatures that are closely related to this research such as previous research reports, journals, internet sites, and sourcebooks. Based on a list of questions raised through interviews and accompanied by supporting data obtained from UPT IKM Cibaduyut about the condition of MSMEs in Cibaduyut and direct observation to several shoe craftsmen in 2018, the analysis was carried out by formulating the problems faced by MSMEs in Cibaduyut, then finding out the cause, and formulate a solution by compiling the four steps of an integrated assistance program consist of planning, implementation, evaluation, and development. After that, design an integrated assistance program model.

\section{RESULTS}

\section{Analysis of Problems Faced by MSMEs}

The results of research conducted by various groups in various regions in Indonesia (Tambunan 2012; Iyuk Wahyudi, 2009; Marliyah, 2016) finally narrowed to a relatively similar conclusion, that actually there are three general aspects that have become the problem of MSMEs so far, namely: Capital aspects, market aspects, and managerial aspects. Problem with the capital aspects are that when MSMEs try to apply for bank credit, they do not understand the making of a suitable loan application proposal, besides that it also often does not fulfill the problem of collateral supply obligations. Problems with market aspects include limited access to market information, limited market reach, lack of marketing, and lack of understanding of consumer needed. The problem of improving the management system is that many MSMEs tend to apply improvised management with the characteristics of a "one man show" management style, less attention to rational considerations, unclear structure and job descriptions, and no employee performance appraisal system.

Based on the results of previous research, we can see that the capital aspect is not the only obstacle faced by MSMEs, as has been predicted by many parties. There are many non-capital constraints that become crucial problems. It is not surprising that various financial approaches (capital) that have been taken by the government, both in the form of channeling revolving funds through relevant departments or institutions or revolving funds of State-Owned Enterprises with the intention to empower MSMEs so far more often end up with a lot of bad loans and usually the impact a 
program to improve MSMEs performance. The pattern of financing that is expected to be able to bring about a snowball effect and is eternal in fact actually only gives birth to a candy effect, which shrinks from time to time until it finally runs out.

Whatever the form of financing patterns for MSMEs, without accompanied by the managerial improvement and market assistance, will only add to the series of failures of various MSMEs empowerment programs. This means that no matter how much MSMEs gets funding stimulant, it will not produce significant benefits, as long as it is not followed by the improvement of the MSMEs institutional and management system itself. This is in line with what was said by Sudaryanto (2015) in his research which stated that "the accompanying function for the MSMEs sector is very crucial because it will determine the extent of the success of the MSMEs existence. This function is in the form of long-term, continuous and complex work."

Accompanying MSMEs actors does not only assist them in the realm of technical nature, but also in the realm of their mental character which must always be built. A strong commitment to business ideals contained in business planning must be interspersed with various kinds of intelligence, especially intelligence fighting (adversity quotient). The factor of integrity and enthusiasm to be a servant is also a big and hard job that must always be instilled in the fostered MSMEs.

Based on the results of observations made in the Cibaduyut area and also the results of the literature review (Tambunan 2012; Iyuk Wahyudi, 2009; Marliyah, 2016; Solehudin, 2019) conducted it can be concluded that the capital aspect is not the only obstacle faced. According to entrepreneurs in Cibaduyut, the problem that is often faced is non-capital problems, namely: 1) Management system issues, there are still many business actors in the Cibaduyut area still using simple management that does not pay attention to rational considerations, job descriptions and less than optimal employee empowerment; 2) Problems with the financial recording system, the majority of business operators in Cibaduyut are home industries, therefore there are still many business actors who still combine business wealth and personal wealth; 3) The problem of capital utilization, in terms of the utilization of available capital obtained from loans is felt to be ineffective so that the number of bad loans has an impact on business bankruptcy.
From the explanation of the problem above, that government programs and other institutions in terms of channeling aid in the form of funds are less able to empower MSMEs to be more independent. A partnership is needed between the central, regional and financial institutions in terms of providing technical assistance to MSMEs so that the guidance can be more integrated (Kementerian Perdagangan, 2017). Therefore, to overcome these problems a model of problem-solving is needed, and the most suitable one with the business climate in the Cibaduyut region is an integrated assistance program. Integrated assistance programs are felt to be appropriate because in this area business operators are only experts in producing products but are very weak in the management system of their business activities.

\section{Integrated Assistance Program}

In order to help improve the ability of micro entrepreneurs, integrated coaching is needed from all elements, especially related agencies, so that micro businesses can develop sustainably which will have an impact on improving the regional economy and the national economy (Joko Sutrisno, 2006). One of the efforts is through an integrated assistance program. The MSMEs integrated assistance program, which is considered quite successful by many researchers, has at least three advantages which are described in Table 2. The three advantages of an integrated assistance programs, where these three advantages can be a solution to the MSMEs problem in Cibaduyut. Advantages that are proactive and intensive can help MSMEs in dealing with problems of capital utilization that have not been effective by going directly to the field to help MSME entrepreneurs in access market information and improve marketing so sales increase and capital turnover faster. Practical and applicative approaches can help SMEs in making financial recording systems according to standards. And emphasizing the success of the personnel approach can help management system problems that have not been well organized.

\section{Design of the MSMEs Integrated Assistance Model}

Integrated assistance is a business assistance program that includes, first: planning, which is to help MSMEs entrepreneurs in preparing plans (action plans) and business targets going forward in a measurable, directed, and reasonable manner. Second: implementation: i.e. 
assisting MSMEs entrepreneurs in carrying out the plans they have drawn up, helping to find solutions when entrepreneurs face obstacles and problems. Third: Evaluation, which also provides an assessment of the performance achieved by the company, and helps entrepreneurs find the cause of deviations from the targets that have been made. Fourth: Development, which helps MSMEs entrepreneurs in developing development plans from the results achieved so far. The following is an explanation the steps of the integrated assistance program for MSMEs in Cibaduyut:

\section{Assisting MSMEs entrepreneurs in preparing a business} (business plan)

Organized by the local government in coordination with the central government and in collaboration with investors and academics. The aim is to stimulate participants to be able to think and act creatively, innovatively and originally, generate a willingness to open or continue micro, small and medium-sized businesses, and assist MSMEs entrepreneurs in preparing action plans and future business targets in a measurable, directed, and reasonable. The result of this effort is that entrepreneurs can create business plans that are in accordance with the planned budget.

Implementation (accompanying MSMEs entrepreneurs in running their business)

Assisting MSMEs entrepreneurs in carrying out the plans they have drawn up, helps find solutions when entrepreneurs face obstacles and problems. The aim is to oversee the implementation of plans that have been made in order to achieve the expected targets. The result of this effort is so that entrepreneurs can run their business independently and develop their business optimally.
Evaluation (provides an assessment of the performance achieved by MSMEs)

Together with entrepreneurs look for the causes of deviations from the business targets to be achieved. The aim is to correct the mistakes that occur during the business run. The result of this effort is so that entrepreneurs do not repeat the same mistakes in running a business.

Development (helping MSMEs entrepreneurs in developing development plans)

Develop a business that has been done so far into an independent business and reach international share. The aim is that the MSMEs that is assisted can stand on its own and become an example for other MSMEs. The result of this effort is that MSMEs become independent and develop rapidly, so they can help the Indonesian economy. And can also provide assistance programs to MSMEs that are not yet independent or in the sense that they still need assistance, so that the government has many mentoring agents.

Table 3 presents the timeline of the MSMEs integrated assistance model which consists of the time of implementation and the type of integrated assistance program activities in accordance with the steps of the MSMEs assistance process. Assistance activities are expected to improve the ability of MSMEs to analyze the results of business simulations, compile financial models so as to be able to utilize capital well, and make conclusions on the performance of companies or organizations with a high degree of accuracy and clarity. From the description of the steps to implement integrated assistance that has been explained above, we can illustrate the model as in Figure 1 which presents the model of an integrated assistance program.

Table 2. Advantages of an integrated assistance program

\begin{tabular}{ll}
\hline Assistance Model & Advantage \\
\hline $\begin{array}{l}\text { Be proactive and } \\
\text { intensive }\end{array}$ & $\begin{array}{l}\text { The program implementing consultants actively, day to day, go into the field to help MSMEs } \\
\text { entrepreneurs. Together, looking for and finding solutions to every MSMEs problem in the field. } \\
\text { Sometimes consultants have to go out of town to accompany entrepreneurs for the sake of lobbying } \\
\text { or problem solving with their business partners. }\end{array}$ \\
$\begin{array}{l}\text { Consultant strategies and policies are tested directly at the practical level. So that it can be } \\
\text { applicative approach }\end{array}$ & $\begin{array}{l}\text { measured how effective ideas or problem-solving consultants are for the advancement of MSMEs. } \\
\text { No longer limited to the concept or just discourse. }\end{array}$ \\
$\begin{array}{l}\text { Emphasize the } \\
\text { success of the } \\
\text { personnel approach }\end{array}$ & $\begin{array}{l}\text { entrepreneurs can trust and want to follow the various advice and input of consultants without } \\
\text { seeming to patronize. }\end{array}$ \\
\hline
\end{tabular}

Source: Iyuk (2009). 
Table 3. Timeline of MSMEs integrated assistance model

\begin{tabular}{lll}
\hline Time & Week & Type of activity \\
\hline January & I and II & MSMEs assistance in making an efficient and effective business plan \\
& III and IV & MSMEs assistance in borrowing capital from banks or other financial institutions \\
February & I and II & MSMEs assistance in managing capital to be effective and efficient \\
& III and IV & MSMEs assistance in the production process \\
March & I - IV & MSMEs assistance in the production process \\
April & I - IV & Assistance to MSMEs in the product marketing process \\
May & I and II & MSMEs assistance in evaluating the business activities that have been carried out \\
& III and IV & MSMEs assistance in business improvement \\
June & I and II & Release of MSMEs to be independent and determine the next targeted MSMEs
\end{tabular}

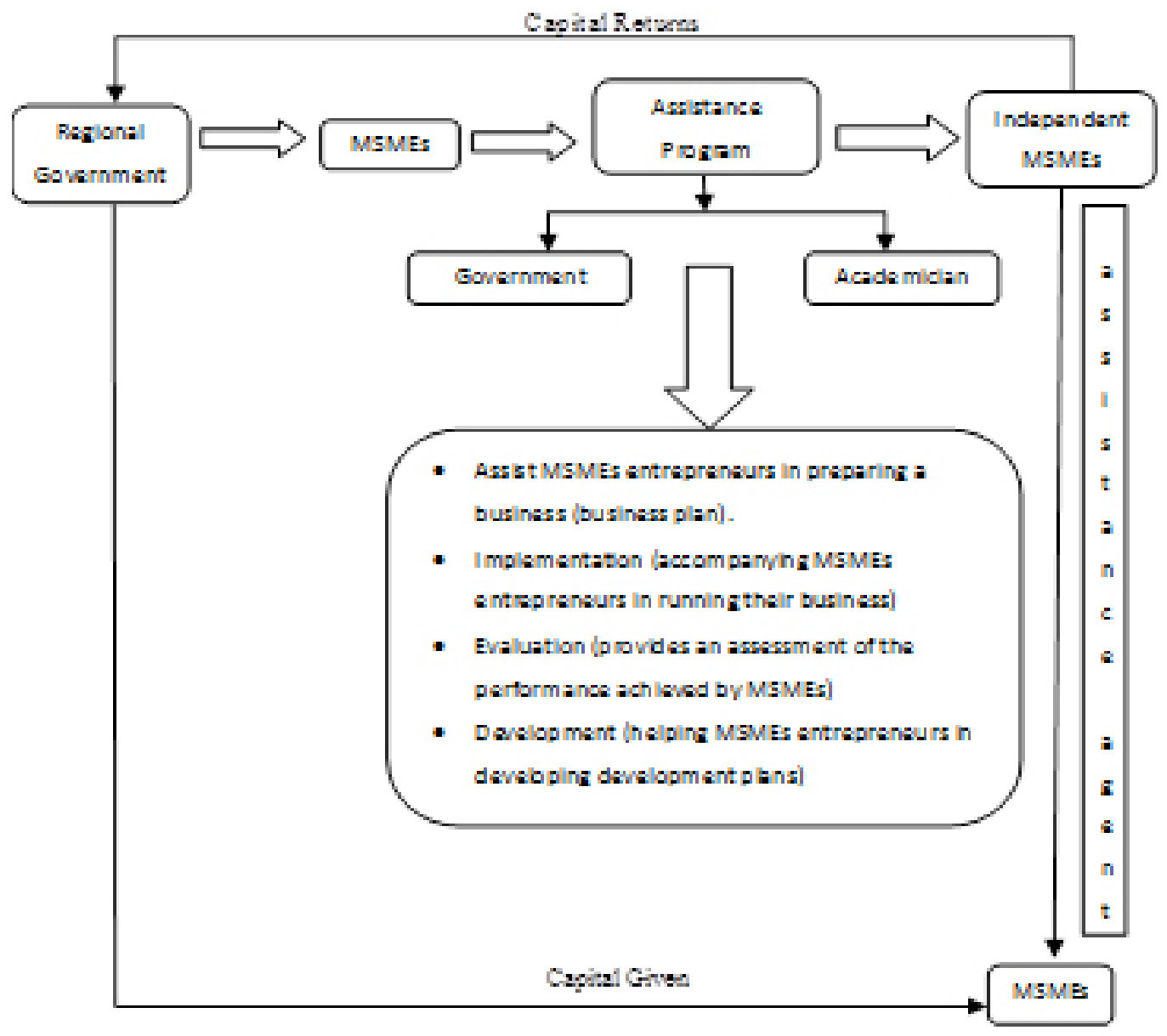

Figure 1. Integrated assistance program

\section{Managerial Implications}

MSMEs that are strong and spread throughout the country are big capital in maintaining and maintaining the unity and integrity of the nation. Supporting this sector at the same time can reduce and neutralize the negative impact of the application of information technology as has happened in many developed countries, namely the widening economic disparity between groups of people. The integrated assistance program will provide convenience and availability of market information for SMEs in Cibaduyut which will greatly help develop their business. If market information can be accessed easily and quickly, it will at least foster motivation for MSMEs to run their business more seriously, so MSMEs develop more advanced. The progress of MSMEs means the economic progress of the country, thereby encouraging the independence of the nation 
to break away from the bonds of neo-colonialism. It will also help the problems that have been faced by MSMEs in Cibaduyut namely to understand about the business processes carried out, be able to create a financial recording system, and be able to utilize capital effectively provided by the government and financial institutions.

\section{CONCLUSIONS AND RECOMMENDATIONS}

\section{Conclusions}

Based on the results of previous studies, there are three common problems for MSMEs, namely capital aspects, market aspects, and managerial aspects. While the problems faced by MSMEs in Cibaduyut are non-capital problems, namely the management system problem, the problem of the financial recording system, and the problem of capital utilization. These problems can be overcome by an integrated assistance program that has three advantages, namely proactive and intensive, practical and applicative approaches, and emphasizes the success of the personnel approach. Integrity assistance programs are felt to be appropriate because in this area business operators are only experts in producing products but are very weak in the management system of their business activities.

Integrated assistance programs are needed to build independent and optimally developing MSMEs. It is expected that the government, academics, and other assistance agents can work together to assist MSMEs entrepreneurs in preparing a business plan, assist MSMEs entrepreneurs in running their businesses, provide an assessment of the performance achieved by MSMEs, and assist MSMEs entrepreneurs in preparing development plans through the design of integrated assistance models that have been arranged.

\section{Recommendations}

For various obstacles faced by MSMEs so far, the following things can be used as solutions that can be considered by policymakers, namely: A partnership is needed between the central, regional and financial institutions in terms of providing technical assistance to MSMEs; To avoid empowerment approaches and methods that create moral danger which in reality will cause empowerment programs to be unproductive, effective and value-added; The need for coordination, consolidation, and integration between departments, local governments, companies, SOEs, universities, and NGO activists to develop and implement an integrated, comprehensive and visionary MSMEs empowerment program.

\section{REFERENCES}

Budi R. 2011. Konsep Pemberdayaan Masyarakat Untuk Usaha Kecil dan Mikro. www.ejournal. unud.ac.id. Diakses pada tahun 2014.

Chabib L. 2016. Pemberdayaan dan Pengembangan UKM Sebagai Penggerak Ekonomi Desa. Asian Journal of Innovation and Entrepreneurship 1(3): 203-209.

Dinas Koperasi, UKM, Perindustrian Perdagangan Kota Bandung. 2018. Perkembangan Sentra Industri Sepatu Cibaduyut. Bandung: Diskukm dan perindag

Hafsah MJ. 2004. Upaya Pengembangan Usaha Kecil dan Menengah (UKM). Infokop $25 \mathrm{XX}$.

Iyuk W. 2009. Program pendampingan terintegrasi:alternatif solusi kendala non-modal bagi UKM.

Joko S, Sri LHS. 2006. Kajian Usaha Mikro Indonesia. Jurnal Pengkajian Koperasi dan UKM 2: 1325.

Kementerian Perdagangan Republik Indonesia. 2017. Analisis Peran Lembaga Pembiayaan dalam Pengembangan UMKM. http://bppp.kemendag. go.id/media_content/2017/08/ANALISIS PERAN_LEMBAGA_PEMBIAYAAN DALAM_PENGEMBANGAN_UMKM.pdf [12 Maret 2020].

Marliyah. 2016. Strategi pembiayaan mudharabah sektor Usaha Mikro, Kecil, dan Menengah (UMKM) [disertation]. Medan: UIN Sumatera Utara

Solehudin M. 2019. Kunjungi Sentra Sepatu Cibaduyut, Sandiaga Dicurhati Omzet Turun. https:// news.detik.com/berita-jawa-barat/d-4397036/ kunjungi-sentra-sepatu-cibaduyut-sandiagadicurhati-omzet-turun [12 Mar2020].

Sumardjo. 2014. Metoda Pemberdayaan Masyarakat secara Partisipatif Sebagai Pendekatan Solusi Konflik. Bogor: CARE IPB.

Susila AR. 2017. Upaya Pengembangan Usaha Mikro Kecil dan Menengah dalam Menghadapi Pasar 
Regional dan Global. Jurnal Kewirausahaan dalam Multi Perspektif. Jakarta: Universitas Terbuka (UT).

Tambunan T. 2012. Usaha Mikro Kecil dan Menengah di Indonesia: IsuIsu Penting. Jakarta: LP3ES.
Sudaryanto, Ragimun, Rahma RW. 2015. Strategi Pemberdayaan UMKM Menghadapi Pasar Bebas Asean. Jakarta: Badan Kebijakan Fiskal Kemenkeu RI. 